\title{
Risk assessments of contemporary accidents in construction industry
}

\author{
Michal Kraus ${ }^{1, *}$ \\ ${ }^{1}$ Institute of Technology and Business in České Budějovice, Department of Civil Engineering, \\ 37001 České Budějovice, Czech Republic
}

\begin{abstract}
The contribution deals with the risk assessments of contemporary accidents in construction in the Czech Republic. The risk analysis is defined as a systematic and structured data processing to identify potential hazards. The risk is a quantitative or qualitative expression of threat. A number of accidents and human errors are characteristic of the construction industry. A zero risk does not exist. An analysis of 615 incidents is presented which identified the location within the building sector in the Czech Republic. The risk analysis including the Risk Assessment Matrix (RAM) is based on secondary data from the Construction and Technical Prevention System (CTPS) in the Czech Republic from 2010 to 2016 . The risk level is determined by the likelihood of occurrence and consequence of defects, faults, and accidents in the construction industry.
\end{abstract}

\section{Introduction}

Construction is the process of constructing a building or infrastructure carried out by workers. This process is always associated with certain risks. Due to the rapid development of infrastructure and building sector, the level of risk from the building sector is rising in the Czech Republic. All human actions carry some level of risk or error. There is no zero risk $[1,2]$. The building can be defined as all construction works that are built by building or assembly technology, regardless of their construction, building materials, and structures, for purpose of use and duration. Terms such as defects, fault, snag, failure, accidents, and crashes are commonly used. There are a number of definitions of these terms, see [3-6]. Building defect can be characterized as a lack of construction due to incorrect design, inadequate or imperfect execution decreasing the performance of structures [1]. The fault can be defined as a change from the original state.

\section{Risk management}

Risk management is a discipline used in all social and technical disciplines, such as natural, engineering, political, and economic or social sciences [7]. Risk management is an integral

\footnotetext{
* Corresponding author: info@krausmichal.cz
} 
part of today's sustainable construction. Risk management is systematic process included risk identification, risk assessment, risk control and prevention. Risk assessment includes quality methods and quantitative methods [2].

\subsection{Risk assessment matrix}

Risk assessment of incidents can be done using a so-called risk matrix. Risk assessment matrix (RAM) is a key tool for risk management. The risk matrix is two-dimensional. Two factors are evaluated - the likelihood and the consequences. Assessment is based on experts with the necessary knowledge and experience. The general risk assessment matrix is shown in Figure 1. According to the ISO 31 000:2009, the likelihood or probability is a chance to something might happen. The consequence is the result of an activity or action that affects the outcome $[2,8,9]$.

Obviously, the higher the likelihood of its occurrence and the higher severity of the consequences is, the risk is more significant. The most significant risks are listed in the upper right quadrant of the matrix. Vice versa, the least significant risks are in the lower left quadrant of the matrix. Generally, there are 4 groups of risk - low, moderate, high and extreme.

Table 1. General Risk Assessment Matrix (RAM) [2].

\begin{tabular}{|c|c|c|c|c|c|}
\hline \multirow[b]{2}{*}{ Likelihood } & \multicolumn{5}{|c|}{ Consequences } \\
\hline & $\begin{array}{c}\text { Insignificant } \\
\text { (1) }\end{array}$ & $\begin{array}{c}\text { Minor } \\
\text { (2) }\end{array}$ & $\begin{array}{c}\text { Moderate } \\
\text { (3) }\end{array}$ & $\begin{array}{c}\text { Major } \\
(4)\end{array}$ & $\begin{array}{c}\text { Catastrophic } \\
\text { (5) }\end{array}$ \\
\hline $\begin{array}{c}\text { Almost certain } \\
\text { (5) }\end{array}$ & $\begin{array}{l}\text { Low } \\
(5)\end{array}$ & $\begin{array}{l}\text { Moderate } \\
\text { (10) }\end{array}$ & $\begin{array}{l}\text { High } \\
(15)\end{array}$ & $\begin{array}{l}\text { Extreme } \\
(20)\end{array}$ & $\begin{array}{l}\text { Extreme } \\
(25)\end{array}$ \\
\hline $\begin{array}{l}\text { Likely } \\
\text { (4) }\end{array}$ & $\begin{array}{l}\text { Low } \\
\text { (4) }\end{array}$ & $\begin{array}{l}\text { Moderate } \\
\text { (8) }\end{array}$ & $\begin{array}{l}\text { High } \\
\text { (12) }\end{array}$ & $\begin{array}{l}\text { Extreme } \\
(16)\end{array}$ & $\begin{array}{l}\text { Extreme } \\
\text { (20) }\end{array}$ \\
\hline $\begin{array}{c}\text { Moderate } \\
\text { (3) } \\
\end{array}$ & $\begin{array}{c}\text { Low } \\
(3) \\
\end{array}$ & $\begin{array}{c}\text { Moderate } \\
(6)\end{array}$ & $\begin{array}{c}\text { Moderate } \\
(9)\end{array}$ & $\begin{array}{l}\text { High } \\
(12) \\
\end{array}$ & $\begin{array}{l}\text { High } \\
(15)\end{array}$ \\
\hline $\begin{array}{c}\text { Unlikely } \\
\text { (2) }\end{array}$ & $\begin{array}{c}\text { Low } \\
(2)\end{array}$ & $\begin{array}{c}\text { Low } \\
(4)\end{array}$ & $\begin{array}{c}\text { Moderate } \\
(6)\end{array}$ & $\begin{array}{c}\text { Moderate } \\
(8)\end{array}$ & $\begin{array}{c}\text { Moderate } \\
(10)\end{array}$ \\
\hline $\begin{array}{c}\text { Rare } \\
\text { (1) }\end{array}$ & $\begin{array}{c}\text { Low } \\
(1)\end{array}$ & $\begin{array}{l}\text { Low } \\
(2)\end{array}$ & $\begin{array}{l}\text { Low } \\
(3)\end{array}$ & $\begin{array}{l}\text { Low } \\
(4)\end{array}$ & $\begin{array}{l}\text { Low } \\
(5)\end{array}$ \\
\hline
\end{tabular}

\section{Incidents in the construction industry}

Figure 1 illustrates the serious accidents in the Czech Republic from 2010 to 2016. The basic statical data are taken from the Construction and Technical Prevention System (CTPS) in the Czech Republic [10]. The Construction and Technical Prevention System collects, monitors and analyses serious or repeated defects in construction. A repeated defect is defined by the third occurrence of an identical or similar defect or defect of the same origin.

The Building Law [11] imposes an obligation to immediately notify the occurrence of a defect, failure or accident of a building if there is a loss of life of persons or animals, a threat to life or the health of persons or animals, a threat to the safety of a building or significant property damage (more than 18000 Euros). Other incidents are not monitored.

Six hundred and fifteen incidents are analyzed in this study. The type of incident, region, and year of origin, building class, functional unit, and severity are monitored. Incidents are divided into 6 basic groups:

- Carbon monoxide poisoning,

- Explosion, 
- Fall from height, caving or injured animal,

- Fall from height, caving or personal injury,

- Fire,

- Structural collapse.

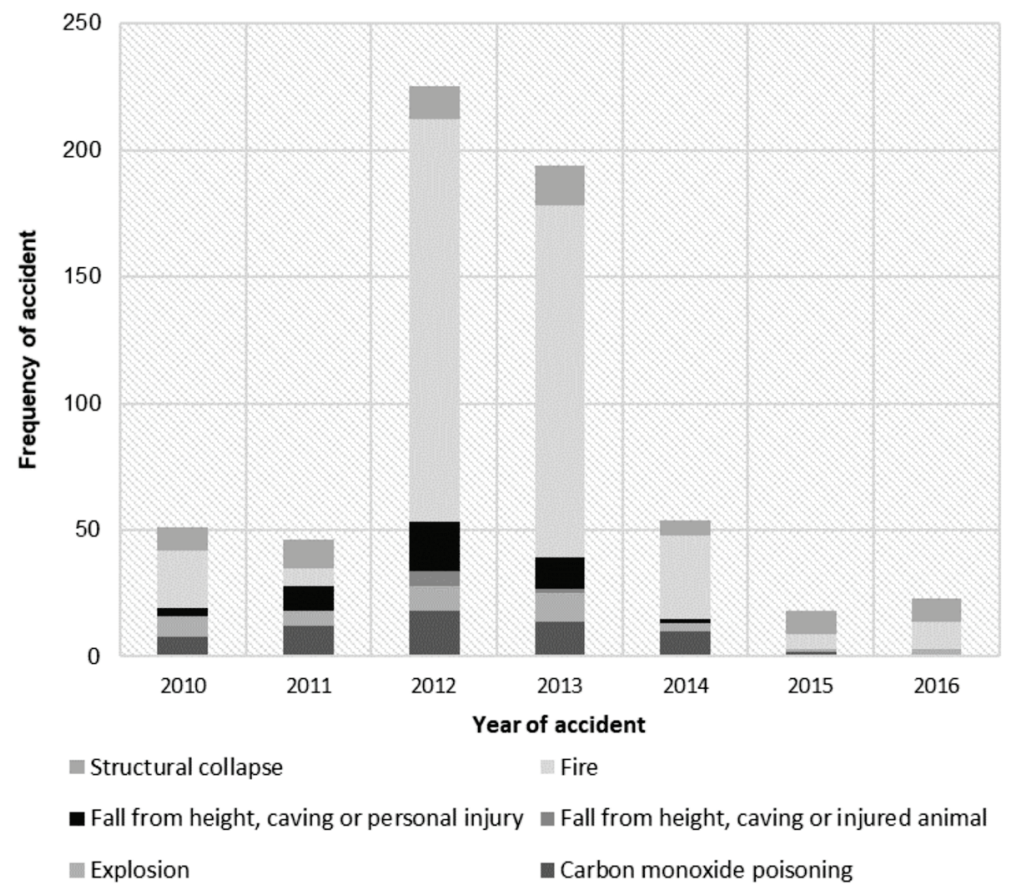

Fig. 1. Overview of accidents by year.

The most serious incidents are monitored in 2012 and 2013. Obviously, the most common incident is a fire. The main causes of fires are the negligent conduct of building users as well as technical faults of functional units of constructions and building equipment [1].

Table 2. Fires by type of building [12].

\begin{tabular}{|l|c|c|c|c|c|c|c|}
\hline Buildings & $\mathbf{2 0 1 0}$ & $\mathbf{2 0 1 1}$ & $\mathbf{2 0 1 2}$ & $\mathbf{2 0 1 3}$ & $\mathbf{2 0 1 4}$ & $\mathbf{2 0 1 5}$ & $\mathbf{2 0 1 6}$ \\
\hline Buildings of civil construction & 588 & 794 & 783 & 665 & 478 & 551 & 547 \\
\hline Apartment houses & 1848 & 1752 & 1737 & 1627 & 1588 & 1619 & 1553 \\
\hline Family houses and other residential buildings & 2087 & 1658 & 1697 & 1629 & 1605 & 1524 & 1847 \\
\hline Buildings and halls for production and services & 324 & 339 & 334 & 324 & 324 & 373 & 354 \\
\hline Energy production building & 79 & 99 & 85 & 98 & 86 & 83 & 97 \\
\hline Garage facilities & 141 & 122 & 121 & 121 & 118 & 116 & 22 \\
\hline Buildings for storage & 139 & 145 & 128 & 91 & 85 & 108 & 114 \\
\hline Buildings for agriculture & 85 & 84 & 78 & 75 & 80 & 50 & 42 \\
\hline Objects under construction & 41 & 61 & 47 & 44 & 33 & 40 & 44 \\
\hline
\end{tabular}


Table 2 illustrates fires by the type of buildings. Data are extracted from the Statistical Yearbooks of the Fire Rescue Service of the Czech Republic from 2010 to 2016 [12]. These data include all fires, not only serious ones.

\subsection{Incident severity level}

The severity of incidents is divided into five groups from least severe (1) to very severe (5): - Considerable damage (1) without injuries and deaths both animals and people. These incidents are characterized by material damage exceeding $€ 18,000$ (the equivalent of 500,000 Czech crowns).

- Threat to lives and health of animals (2)

- Loss of life of animal (3)

- Threat to lives and health of people (4)

- Loss of life of people (fatality) (5).

According to the figure 2 , more than $50 \%$ result in personal injury $(37 \%)$ or death (14\%). Almost $50 \%$ of the incidents can be classified in the first degree of severity. Injury to animals or their death is minimal.

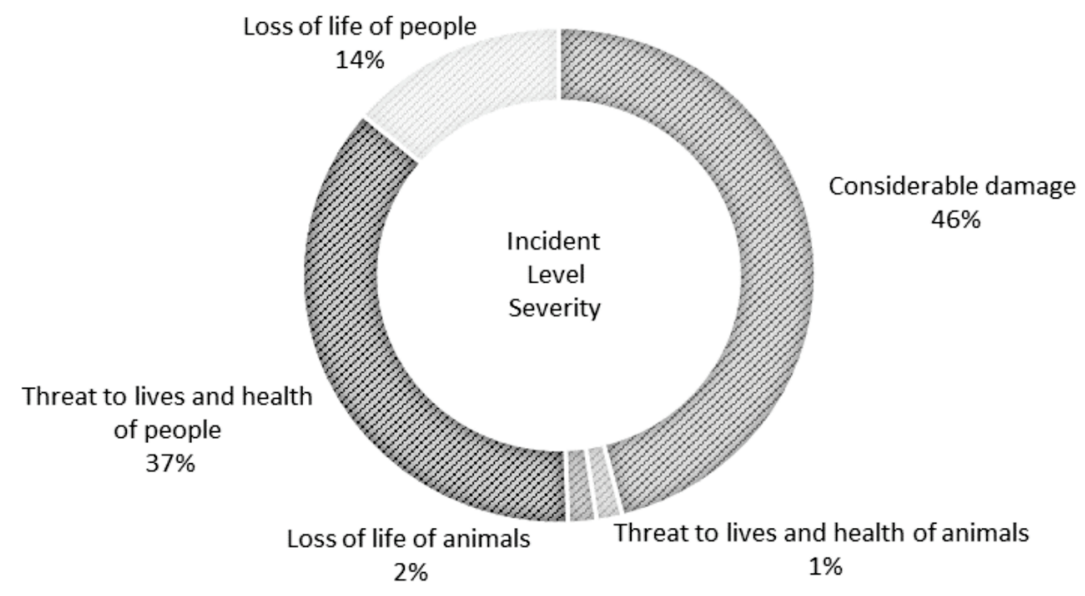

Fig. 2. Incident level severity.

\subsection{Risk matrix}

The risk level is a value of a risk derived from its likelihood and consequence. The scoring (multiple of the likelihood and the severe) reflects the priority and urgency of adopting measures to reduce risk (Table 3 ).

The likelihood of an incident $(p)$ is defined as the proportion of the frequency of the type of incident and the number of all incidents monitored. The severity $(s)$ is expressed by:

$$
s=\Sigma\left(s_{i} \cdot n_{i}\right) / n
$$

where $s$ is the severity of the type of incident [-],

$\mathrm{S}_{\mathrm{i}}$ is the degree of severity of the incident (1-5) [-],

$\mathrm{n}_{\mathrm{i}}$ is the frequency of incidents for the degree severity [-], 
$n$ is the frequency of the type of incidents [-].

Table 4 shows the results of the risk analysis. In term technical viewpoint, the risk R3 is insignificant and acceptable. This risk can be ignored. The risks R4, R5, and R6 are regarded as moderate. They are not high-priority. It is necessary to pay attention to risks R1 and R2. A particularly R2 represents an extreme risk. This risk has extremely negative consequences and it is the highest priority.

Table 3. Risk assessment table of incidents of contemporary constructions.

\begin{tabular}{|c|c|c|c|c|c|}
\hline \multicolumn{2}{|c|}{ Risks } & $\begin{array}{c}\text { Likelihood } \\
(1-5)\end{array}$ & $\begin{array}{c}\text { Consequence } \\
(1-5)\end{array}$ & $\begin{array}{c}\text { Overall } \\
\text { Risk } \\
(1-25)\end{array}$ & $\begin{array}{c}\text { Risk } \\
\text { level }\end{array}$ \\
\hline R1 & Carbon monoxide poisoning & $\begin{array}{c}3 \\
(p=0.106)\end{array}$ & $\begin{array}{c}4 \\
(s=4.185)\end{array}$ & 12 & High \\
\hline R2 & Explosion & $\begin{array}{c}2 \\
(p=0.067)\end{array}$ & $\begin{array}{c}4 \\
(\mathrm{~s}=3.610)\end{array}$ & 8 & Extreme \\
\hline R3 & Fall from height, caving or injured & $\begin{array}{c}1 \\
\text { animal }\end{array}$ & $\begin{array}{c}2 \\
(\mathrm{~s}=2.000)\end{array}$ & 2 & Low \\
\hline R4 & Fall from height, caving or personal \\
injury & $\begin{array}{c}2 \\
(\mathrm{p}=0.072)\end{array}$ & $\begin{array}{c}4 \\
(\mathrm{~s}=4.409)\end{array}$ & 8 & Moderate \\
\hline R5 & Fire & $\begin{array}{c}5 \\
(\mathrm{p}=0.619)\end{array}$ & $\begin{array}{c}2 \\
(\mathrm{~s}=2.124)\end{array}$ & 10 & Moderate \\
\hline R6 & Structural collapse & $\begin{array}{c}3 \\
(\mathrm{~s}=3.026)\end{array}$ & 9 & Moderate \\
\hline
\end{tabular}

Table 4. Risk Assessment Matrix of incidents of contemporary constructions.

\begin{tabular}{|c|c|c|c|c|c|}
\hline \multirow{2}{*}{ Likelihood } & \multicolumn{5}{|c|}{ Consequences } \\
\cline { 2 - 6 } & $\begin{array}{c}\text { Insignificant } \\
\text { (1) }\end{array}$ & $\begin{array}{c}\text { Minor } \\
\text { (2) }\end{array}$ & $\begin{array}{c}\text { Moderate } \\
\text { (3) }\end{array}$ & $\begin{array}{c}\text { Major } \\
\text { (4) }\end{array}$ & $\begin{array}{c}\text { Catastrophic } \\
\text { (5) }\end{array}$ \\
\hline $\begin{array}{c}\text { Almost certain } \\
\text { (5) }\end{array}$ & & $\begin{array}{c}\text { R5 } \\
\text { Moderate }\end{array}$ & & & \\
\hline $\begin{array}{c}\text { Likely } \\
\text { (4) }\end{array}$ & & & & $\begin{array}{c}\text { R2 } \\
\text { Extreme }\end{array}$ & \\
\hline $\begin{array}{c}\text { Moderate } \\
\text { (3) }\end{array}$ & & & R6 & R1 & \\
\hline $\begin{array}{c}\text { Unlikely } \\
\text { (2) }\end{array}$ & & & Moderate & \\
\hline $\begin{array}{c}\text { Rare } \\
\text { (1) }\end{array}$ & & R3 & & R4 \\
Loderate & \\
\hline
\end{tabular}

\section{Conclusion}

The risk is perceived as a measure of the risk of injury or the occurrence (in extreme case to death) or financial damage. According to the semi-quantitative risk assessment, the results clearly indicate the significance of the incidents - defects, faults, and accidents. The fire, structural collapse and personal injury have a moderate degree of risk. The most frequent incidents are fires of buildings or building elements. On the contrary, the smallest probability of occurrence is the fall from a height, caving or injured an animal. The risk of injury or death of animals is low. Extreme risk is the explosion. Carbon dioxide poisoning has a high risk. These risks have a high priority and it is necessary to pay attention to these risks and to minimize them. 


\section{References}

1. M. Kraus, T. Vondráčková, V. Nývlt, Matec Web of Conferences 93, 03004 (2017)

2. M. Kraus, P. Bednářová, K. Kubečka, AMM 824, 657-664 (2016).

3. Act No. 183/2006 Coll., on town planning and the building code (the Building Act)

4. J. Alencastro, A. Fuertes, P. de Wilde, Renewable and Sustainable Energy Reviews 81, part 1, 883-891 (2018).

5. N. Forcada, M. Macarulla, M. Gangolells, M. Casals. Build Res Inf 42, 629-640 (2014).

6. M. Macarulla, N. Forcada, M. Casals, M. Gangolells, A. Fuertes, X. Roca. J Constr Eng Manag 139, 968-976 (2013).

7. R.E. Hester, R.M. Harrison. Risk Assessment and Risk Management (Royal Society of Chemistry, 1998)

8. A.M. Doro-on. Risk Assessment and Security for Pipelines, Tunnels, and Underground Rail and Transit Operations (CRC Press, 2014)

9. Institute for Spatial Development. Construction and Technical Prevention System. Available on https://www.uur.cz/?id=948

10. Smartsheet. All the Risk Assessment Matrix Templates You Need. Available on https://www.smartsheet.com/all-risk-assessment-matrix-templates-you-need

11. Law no. 183/2006 Sb on Planning and Building Code (Prague, 2006)

12. Fire Rescue Service of the Czech Republic. Statistical Yearbooks 2010 - 2016. available on http://www.hzscr.cz/hasicien/article/statistical+-yearbooks.aspx 